\title{
Effect of Cytokines on Osteoclast Formation
} and Bone Resorption during Mechanical Force Loading of the Periodontal Membrane

\author{
Hideki Kitaura, ${ }^{1}$ Keisuke Kimura, ${ }^{1}$ Masahiko Ishida, ${ }^{1}$ Haruki Sugisawa, ${ }^{1}$ Haruka Kohara, ${ }^{2}$ \\ Masako Yoshimatsu, ${ }^{2}$ and Teruko Takano-Yamamoto ${ }^{1}$ \\ ${ }^{1}$ Division of Orthodontics and Dentofacial Orthopedics, Department of Translational Medicine, \\ Tohoku University Graduate School of Dentistry, 4-1 Seiryo-machi, Aoba-ku, Sendai 980-8575, Japan \\ ${ }^{2}$ Department of Orthodontics and Dentofacial Orthopedics, Nagasaki University Graduate School of Biomedical Sciences, \\ Nagasaki 852-8588, Japan \\ Correspondence should be addressed to Hideki Kitaura; hkitaura@m.tohoku.ac.jp
}

Received 31 August 2013; Accepted 20 November 2013; Published 19 January 2014

Academic Editors: E. L. Hooghe-Peters, C. Rosales, and H. Taki

Copyright (C) 2014 Hideki Kitaura et al. This is an open access article distributed under the Creative Commons Attribution License, which permits unrestricted use, distribution, and reproduction in any medium, provided the original work is properly cited.

\begin{abstract}
Mechanical force loading exerts important effects on the skeleton by controlling bone mass and strength. Several in vivo experimental models evaluating the effects of mechanical loading on bone metabolism have been reported. Orthodontic tooth movement is a useful model for understanding the mechanism of bone remodeling induced by mechanical loading. In a mouse model of orthodontic tooth movement, TNF- $\alpha$ was expressed and osteoclasts appeared on the compressed side of the periodontal ligament. In TNF-receptor-deficient mice, there was less tooth movement and osteoclast numbers were lower than in wild-type mice. These results suggest that osteoclast formation and bone resorption caused by loading forces on the periodontal ligament depend on TNF- $\alpha$. Several cytokines are expressed in the periodontal ligament during orthodontic tooth movement. Studies have found that inflammatory cytokines such as IL-12 and IFN- $\gamma$ strongly inhibit osteoclast formation and tooth movement. Blocking macrophage colony-stimulating factor by using anti-c-Fms antibody also inhibited osteoclast formation and tooth movement. In this review we describe and discuss the effect of cytokines in the periodontal ligament on osteoclast formation and bone resorption during mechanical force loading.
\end{abstract}

\section{Osteoclast Differentiation}

Osteoclasts, derived from hematopoietic stem cells, control bone resorption [1]. Two factors that influence the formation of mature osteoclasts have been identified. The first is receptor activator of NF- $\kappa \mathrm{B}$ ligand (RANKL) [2], also called osteoclast differentiation factor (ODF) [3], osteoprotegerin ligand (OPGL) [4], or TNF-related activation-induced cytokine (TRANCE) [5]. The second factor is macrophage colony-stimulating factor (M-CSF), which is essential for the proliferation and differentiation of osteoclast precursors [6]. Osteopetrotic (op/op) mice, which are deficient in MCSF, show a lack of osteoclast development [7]. It has been reported that TNF- $\alpha$ mediates osteoclast formation in vitro $[8-10]$ and in vivo $[11,12]$. TNF- $\alpha$-induced osteoclast recruitment is probably central to the pathogenesis of inflammatory disorders [13]. TNF- $\alpha$ is a known cause of rheumatoid arthritis [14], periodontal diseases [15], and postmenopausal osteoporosis [16]. TNF- $\alpha$ can induce biological reactions via two cell-surface receptors: TNF receptor type 1 (TNFR1) and TNF receptor type 2 (TNFR2). Each receptor mediates different intracellular signals. Analysis of TNFR1and TNFR2-deficient mice revealed that TNFR1 induces osteoclast differentiation, while TNFR2 inhibits osteoclast differentiation [17]. The role of TNF- $\alpha$ signaling in osteoclastogenesis remains poorly understood, and further studies are needed to clarify the relationship between TNF- $\alpha$ and osteoclast differentiation. 


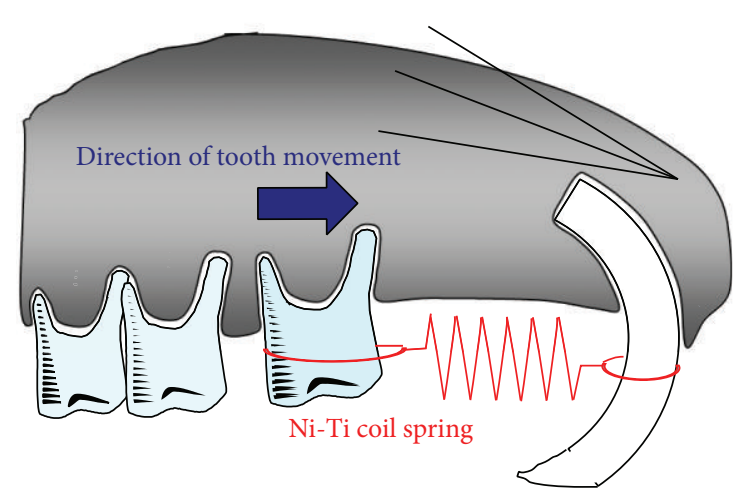

FIGURE 1: Schema of appliance for orthodontic tooth movement in mice. The orthodontic appliance is composed of a Ni-Ti coil spring. The appliance was inserted between the upper incisors and the upper left first molar and fixed with a $0.1 \mathrm{~mm}$ stainless wire around both teeth.

\section{Mechanical Loading}

Mechanical loading has important effects on skeletal bone mass and strength [18]. Several in vivo experiments have evaluated the effects of mechanical loading on bone metabolism, with mechanical loading caused by jumping $[19,20]$, treadmill running [21, 22], squatting [23], and swimming [24]. Orthodontic tooth movement is another useful in vivo model for elucidating the mechanism of mechanical loadinginduced bone remodeling [25-28]. Orthodontic tooth movement has mainly been studied in rat and mouse models [29-37]. Recent advances in molecular biology techniques have provided opportunities for the use of gene-mutated mice, including those with mutations in genes that regulate bone metabolism. Mouse models of tooth movement can be advantageous in understanding the molecular mechanisms not only of tooth movement but also of mechanical loadinginduced bone remodeling. In the mouse model, Ni-Ti coil springs are most suitable for exerting continuous orthodontic force $[38,39]$ (Figure 1). Orthodontic tooth movement is achieved by the process of alveolar bone resorption on the compression side and new bone formation on the tension side [40] (Figure 2). There is an association between osteoclasts and bone resorption on the compression side during orthodontic tooth movement [41]. In a mouse model, bone resorption and tartrate-resistant acid phosphatase- (TRAP-) positive multinuclear cells were recognized on the compression side.

\section{TNF- $\alpha$-Mediated Mechanical Loading-Induced Osteoclast Formation and Bone Resorption}

Mechanical forces affect tooth movement via the biological responses of cells in the periodontal ligament, the alveolar bone, and other paradental tissues [42]. Several cytokines and hormones are involved in this process. It has been reported that orthodontic tooth movement increases levels of TNF- $\alpha$ in the gingival sulcus in humans $[43,44]$. It has been shown that TNF- $\alpha$ is expressed in rat periodontal tissue under pathological conditions resulting from excessive orthodontic force [45]. When a tooth movement system was applied to mice deficient in TNFR1 or TNFR2, less tooth movement was observed in TNFR2-deficient mice than in wild-type mice [38]. This result suggests that TNFR2 is important for orthodontic tooth movement. On the other hand, conflicting results were reported in a study of TNFR1- and TNFR2deficient mice, which found increased osteoclast formation in TNFR1-deficient mice, with inhibited osteoclast formation in TNFR2-deficient mice [17]. Andrade et al. evaluated the effect of TNFR1 on osteoclast formation in orthodontic tooth movement. The number of osteoclasts in TNFR1-deficient mice was lower than in wild-type mice [46]. To further confirm the role of TNFRs, we performed tooth movement experiments using mice with mutations in both TNFR1 and TNFR2. We found a significant decrease in tooth movement in the double mutated mice [39]. These results suggest that TNF- $\alpha$ affects orthodontic tooth movement. However, the relationship between orthodontic movement and TNF- $\alpha$ is not fully understood.

\section{Effect of Cytokines on Mechanical Loading-Induced Osteoclast Formation and Bone Resorption}

Cytokines in the gingival area during orthodontic tooth treatment provide information about local cellular metabolism, reflecting the status of periodontal health and bone remodeling. Many investigators have found cytokine expression in the gingival area during orthodontic tooth movement. The course of osteoclast formation can be controlled by cytokines. Interleukin- (IL-) 6 [47], IL-17 [48], and transforming growth factor- $\beta[49]$ induce osteoclast formation and increase bone resorption by osteoclasts. Conversely, IL-4 [50, 51], IL-10 [52], IL-12 [53-56], IL-13 [57], IL-18 [58-60], and IFN- $\gamma$ $[49,61]$ inhibit osteoclast formation and several osteoclast functions. IL-4 [50, 51], IL-12 [55, 56], IL-18 [59, 60], and IFN- $\gamma$ [61] inhibit TNF- $\alpha$-induced osteoclast formation in vitro and in vivo. It has been reported that the cytokines IL-1 $\beta$ [62], TNF- $\alpha[38,43,44]$, IL-6 [63-65], IL-8 [64, 65], RANKL [66], M-CSF [67], TGF- $\beta$ [68], IL-2 [65], and IFN- $\gamma$ [69] were locally increased during orthodontic tooth movement. These cytokines may affect osteoclast formation during orthodontic tooth movement. We previously reported that TNF- $\alpha$ is expressed on the compression side of the tooth and plays an important role in mechanical tooth movement [38]. Therefore, we examined whether these cytokines inhibit mechanical tooth movement. We found that IFN- $\gamma$ inhibited osteoclastogenesis during orthodontic tooth movement, suggesting that experimental tooth movement may cause TNF- $\alpha$-induced osteoclastogenesis that is then inhibited by IFN- $\gamma$ [69]. In another study using a rat model, IFN- $\gamma$ inhibited osteoclast formation on the compression side during experimental tooth movement, as shown by immunohistochemical staining [70]. These results suggest that IFN $-\gamma$ might control excessive osteoclastogenesis during orthodontic tooth movement. We previously demonstrated 


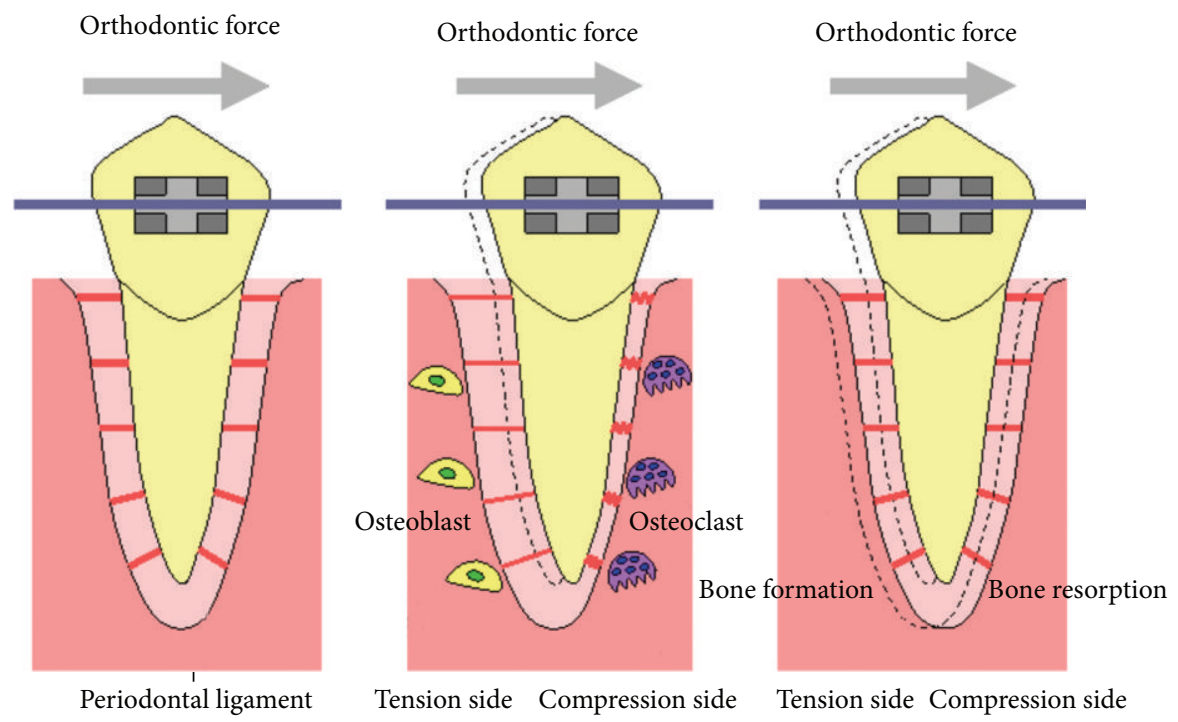

Figure 2: Schematic diagram of tooth movement. Applying orthodontic force to the tooth causes compression of the periodontal ligament. The compressed side of periodontal ligament is called the compression side and the side where the periodontal ligament is pulled is called the tension side. Osteoclasts appear on the compression side and osteoblasts on the tension side. The tooth moves as osteoclasts resorb bone while osteoblasts form bone.

IL-12-induced apoptosis of osteoclast precursor cells during osteoclastogenesis $[55,56]$. In these studies, we found that IL12 inhibited TNF- $\alpha$-mediated osteoclastogenesis by inducing apoptotic changes in osteoclast precursor cells through interactions between TNF- $\alpha$-induced Fas and IL-12-induced FasL. We also investigated whether IL-12 inhibits mechanical tooth movement. IL-12 inhibited mechanical tooth movement through inhibition of osteoclastogenesis and bone resorption on the pressure side of teeth [71]. Many apoptotic cells were also recognized on the pressure side in IL-12-treated mice. Apoptosis may be caused by the interactions between TNF$\alpha$-induced Fas and IL-12-induced FasL in orthodontic tooth movement. Our results led us to conclude that IFN- $\gamma$ and IL12 induction inhibit osteoclastogenesis and tooth movement caused by mechanical force loading.

\section{Effects of M-CSF on Mechanical Loading-Induced Osteoclast Formation and Bone Resorption}

M-CSF is well known as an essential factor in osteoclast formation. It has been reported that administration of $\mathrm{M}$ CSF receptor c-Fms antibody completely blocks osteoclastogenesis and bone erosion induced by TNF- $\alpha$ administration or inflammatory arthritis [12]. Orthodontic tooth movement is also mediated by TNF- $\alpha$. Therefore, we hypothesized that anti-c-Fms antibody might block osteoclastogenesis and bone resorption at the compression side of a tooth undergoing orthodontic tooth movement. In our study, anti-c-Fms antibody injected daily into a local site for 12 days during mechanical loading significantly inhibited orthodontic tooth movement and markedly reduced the number of osteoclasts in vivo [39]. Brooks et al. showed that injection of $\mathrm{M}$ CSF accelerated orthodontic tooth movement and osteoclast formation [72]. These results suggest that control of M-CSF could regulate osteoclast formation and tooth movement in orthodontic treatments. The receptor tyrosine kinase inhibitor SU11248 prevents activation of the M-CSF receptor, inhibiting osteoclast formation and function in vitro and in vivo [73]. The tyrosine kinase inhibitor imatinib also inhibits the M-CSF receptor. These results suggest the possibility of drug treatment for bone destruction [74]. However, the therapeutic use of M-CSF must be approached with caution because significant complications have been encountered with other forms of anticytokine therapy [75]. Further studies are necessary to evaluate the therapeutic use of M-CSF.

\section{Root Resorption}

Root resorption is a possible complication of orthodontic treatment and is a serious problem for orthodontists. Several studies have suggested that excessive orthodontic force is a critical factor in root resorption $[76,77]$. It has been reported that root resorption is associated with tooth morphology [78], tooth intrusion [79, 80], periodontal condition [81], and systemic factors such as genetics [82], the immune system [83, 84], and bone metabolism [85, 86]. In our mouse orthodontic tooth movement system, a $\mathrm{Ni}-\mathrm{Ti}$ coil spring was inserted between the upper incisors and the upper first molar. Root resorption occurred in this model [87]. Root resorption results from the activity of odontoclasts, which play a role similar to that of osteoclasts in bone resorption. Like osteoclasts, odontoclasts are multinucleated giant TRAP-positive cells with ruffled borders [88]. Tsuchiya et al. reported that odontoclasts had fewer nuclei, smaller TRAP-positive area, and higher expression of MMP-9 than osteoclasts [89]. It remains unclear whether odontoclasts and osteoclasts can be considered functionally 
identical. We tested our hypothesis that IL-12 and anti-cFms antibody might inhibit odontoclastogenesis and root resorption during orthodontic tooth movement by injecting IL-12 locally adjacent to the first molar every other day during the experimental period. We found that IL-12 inhibited odontoclastogenesis and root resorption during orthodontic tooth movement [71]. Anti-c-Fms antibody also significantly inhibited odontoclastogenesis and root resorption during orthodontic tooth movement [87]. M-CSF and its receptor are potential therapeutic targets in mechanical stress-induced odontoclastogenesis, and injection of an anti-c-Fms antibody might be useful to prevent mechanical stress-induced root resorption during orthodontic tooth movement.

\section{Conclusion}

Many studies have reported the expression of various cytokines during mechanical loading of the periodontal ligament. Several studies using gene-mutated mice have shown that TNF- $\alpha$ plays a key role in mechanical force loading-induced osteoclast formation in the periodontal ligament. Therefore, it is important to study the relationship between TNF- $\alpha$-induced osteoclast formation and cytokines expressed during mechanical loading. Further studies are needed to fully understand the effect of cytokines on mechanical loading-induced osteoclast formation.

\section{Conflict of Interests}

The authors declare that there is no conflict of interests regarding the publication of this paper.

\section{References}

[1] T. Suda, N. Takahashi, and T. J. Martin, "Modulation of osteoclast differentiation," Endocrine Reviews, vol. 13, no. 1, pp. 66-80, 1992.

[2] D. M. Anderson, E. Maraskovsky, W. L. Billingsley et al., "A homologue of the TNF receptor and its ligand enhance T-cell growth and dendritic-cell function," Nature, vol. 390, no. 6656, pp. 175-179, 1997.

[3] H. Yasuda, N. Shima, N. Nakagawa et al., "Osteoclast differentiation factor is a ligand for osteoprotegerin/ osteoclastogenesisinhibitory factor and is identical to TRANCE/RANKL," Proceedings of the National Academy of Sciences of the United States of America, vol. 95, no. 7, pp. 3597-3602, 1998.

[4] D. L. Lacey, E. Timms, H.-L. Tan et al., "Osteoprotegerin ligand is a cytokine that regulates osteoclast differentiation and activation," Cell, vol. 93, no. 2, pp. 165-176, 1998.

[5] B. R. Wong, J. Rho, J. Arron et al., "TRANCE is a novel ligand of the tumor necrosis factor receptor family that activates c-Jun Nterminal kinase in T cells," The Journal of Biological Chemistry, vol. 272, no. 40, pp. 25190-25194, 1997.

[6] H. Kodama, M. Nose, S. Niida, and A. Yamasaki, "Essential role of macrophage colony-stimulating factor in the osteoclast differentiation supported by stromal cells," The Journal of Experimental Medicine, vol. 173, no. 5, pp. 1291-1294, 1991.

[7] J. W. Wiktor, A. Bartocci, A. W. Ferrante Jr. et al., "Total absence of colony-stimulating factor 1 in the macrophagedeficient osteopetrotic (op/op) mouse," Proceedings of the
National Academy of Sciences of the United States of America, vol. 87, no. 12, pp. 4828-4832, 1990.

[8] Y. Azuma, K. Kaji, R. Katogi, S. Takeshita, and A. Kudo, “Tumor necrosis factor- $\alpha$ induces differentiation of and bone resorption by osteoclasts," The Journal of Biological Chemistry, vol. 275, no. 7, pp. 4858-4864, 2000.

[9] K. Kobayashi, N. Takahashi, E. Jimi et al., "Tumor necrosis factor $\alpha$ stimulates osteoclast differentiation by a mechanism independent of the ODF/RANKL-RANK interaction," The Journal of Experimental Medicine, vol. 191, no. 2, pp. 275-286, 2000.

[10] K. Fuller, C. Murphy, B. Kirstein, S. W. Fox, and T. J. Chambers, "TNF $\alpha$ potently activates osteoclasts, through a direct action independent of and strongly synergistic with RANKL," Endocrinology, vol. 143, no. 3, pp. 1108-1118, 2002.

[11] H. Kitaura, M. S. Sands, K. Aya et al., "Marrow stromal cells and osteoclast precursors differentially contribute to TNF- $\alpha$ induced osteoclastogenesis in vivo," The Journal of Immunology, vol. 173, no. 8, pp. 4838-4846, 2004.

[12] H. Kitaura, P. Zhou, H.-J. Kim, D. V. Novack, F. P. Ross, and S. L. Teitelbaum, "M-CSF mediates TNF-induced inflammatory osteolysis," The Journal of Clinical Investigation, vol. 115, no. 12, pp. 3418-3427, 2005.

[13] M. Wong, D. Ziring, Y. Korin et al., "TNF $\alpha$ blockade in human diseases: mechanisms and future directions," Clinical Immunology, vol. 126, no. 2, pp. 121-136, 2008.

[14] K. Redlich, S. Hayer, R. Ricci et al., "Osteoclasts are essential for TNF- $\alpha$-mediated joint destruction," The Journal of Clinical Investigation, vol. 110, no. 10, pp. 1419-1427, 2002.

[15] Y. Abu-Amer, F. P. Ross, J. Edwards, and S. L. Teitelbaum, "Lipopolysaccharide-stimulated osteoclastogenesis is mediated by tumor necrosis factor via its P55 receptor," The Journal of Clinical Investigation, vol. 100, no. 6, pp. 1557-1565, 1997.

[16] R. B. Kimble, S. Srivastava, F. P. Ross, A. Matayoshi, and R. Pacifici, "Estrogen deficiency increases the ability of stromal cells to support murine osteoclastogenesis via an interleukin-1and tumor necrosis factor-mediated stimulation of macrophage colony-stimulating factor production," The Journal of Biological Chemistry, vol. 271, no. 46, pp. 28890-28897, 1996.

[17] Y. Abu-Amer, J. Erdmann, L. Alexopoulou, G. Kollias, F. Patrick Ross, and S. L. Teitelbaum, "Tumor necrosis factor receptors types 1 and 2 differentially regulate osteoclastogenesis," The Journal of Biological Chemistry, vol. 275, no. 35, pp. 27307-27310, 2000.

[18] H. M. Frost, "On our age-related bone loss: insights from a new paradigm," Journal of Bone and Mineral Research, vol. 12, no. 10, pp. 1539-1546, 1997.

[19] T. Notomi, S. J. Lee, N. Okimoto et al., "Effects of resistance exercise training on mass, strength, and turnover of bone in growing rats," European Journal of Applied Physiology, vol. 82, no. 4, pp. 268-274, 2000.

[20] Y. Kodama, Y. Umemura, S. Nagasawa et al., "Exercise and mechanical loading increase periosteal bone formation and whole bone strength in C57BL/6J mice but not in $\mathrm{C} 3 \mathrm{H} / \mathrm{Hej}$ mice," Calcified Tissue International, vol. 66, no. 4, pp. 298-306, 2000.

[21] J. Iwamoto, J. K. Yeh, and J. F. Aloia, "Differential effect of treadmill exercise on three cancellous bone sites in the young growing rat," Bone, vol. 24, no. 3, pp. 163-169, 1999.

[22] T. Notomi, Y. Okazaki, N. Okimoto, S. Saitoh, T. Nakamura, and M. Suzuki, "A comparison of resistance and aerobic training for mass, strength and turnover of bone in growing rats," European Journal of Applied Physiology, vol. 83, no. 6, pp. 469-474, 2000. 
[23] K. C. Westerlind, J. D. Fluckey, S. E. Gordon, W. J. Kraemer, P. A. Farrell, and R. T. Turner, "Effect of resistance exercise training on cortical and cancellous bone in mature male rats," Journal of Applied Physiology, vol. 84, no. 2, pp. 459-464, 1998.

[24] K. J. Hart, J. M. Shaw, E. Vajda, M. Hegsted, and S. C. Miller, "Swim-trained rats have greater bone mass, density, strength, and dynamics," Journal of Applied Physiology, vol. 91, no. 4, pp. 1663-1668, 2001.

[25] E. Storey, "The nature of tooth movement," The American Journal of Orthodontics, vol. 63, no. 3, pp. 292-314, 1973.

[26] T. Takano-Yamamoto, T. Takemura, Y. Kitamura, and S. Nomura, "Site-specific expression of mRNAs for osteonectin, osteocalcin, and osteopontin revealed by in situ hybridization in rat periodontal ligament during physiological tooth movement," The Journal of Histochemistry and Cytochemistry, vol. 42, no. 7, pp. 885-896, 1994.

[27] Y. Ohba, T. Ohba, K. Terai, and K. Moriyama, "Expression of cathepsin $\mathrm{K}$ mRNA during experimental tooth movement in rat as revealed by in situ hybridization," Archives of Oral Biology, vol. 45, no. 1, pp. 63-69, 2000.

[28] Y. Kobayashi, F. Hashimoto, H. Miyamoto et al., "Force-induced osteoclast apoptosis in vivo is accompanied by elevation in transforming growth factor $\beta$ and osteoprotegerin expression," Journal of Bone and Mineral Research, vol. 15, no. 10, pp. 19241934, 2000.

[29] F. Hashimoto, Y. Kobayashi, S. Mataki, K. Kobayashi, Y. Kato, and H. Sakai, "Administration of osteocalcin accelerates orthodontic tooth movement induced by a closed coil spring in rats," European Journal of Orthodontics, vol. 23, no. 5, pp. 535545, 2001.

[30] P. Brudvik and P. Rygh, "The initial phase of orthodontic root resorption incident to local compression of the periodontal ligament," European Journal of Orthodontics, vol. 15, no. 4, pp. 249-263, 1993.

[31] D. Pavlin, S. B. Dove, R. Zadro, and J. Gluhak-Heinrich, "Mechanical loading stimulates differentiation of periodontal osteoblasts in a mouse osteoinduction model: effect on type I collagen and alkaline phosphatase genes," Calcified Tissue International, vol. 67, no. 2, pp. 163-172, 2000.

[32] M. Kaku, S. Kohno, T. Kawata et al., "Effects of vascular endothelial growth factor on osteoclast induction during tooth movement in mice," Journal of Dental Research, vol. 80, no. 10, pp. 1880-1883, 2001.

[33] Y. Tsuji, T. Yamaza, M. A. Kido et al., "Expression of cathepsin $\mathrm{K}$ mRNA and protein in odontoclasts after experimental tooth movement in the mouse maxilla by in situ hybridization and immunoelectron microscopy," Cell and Tissue Research, vol. 303, no. 3, pp. 359-369, 2001.

[34] J. Gluhak-Heinrich, L. Ye, L. F. Bonewald et al., "Mechanical loading stimulates dentin matrix protein 1 (DMP1) expression in osteocytes in vivo," Journal of Bone and Mineral Research, vol. 18, no. 5, pp. 807-817, 2003.

[35] S. Kohno, M. Kaku, K. Tsutsui et al., "Expression of vascular endothelial growth factor and the effects on bone remodeling during experimental tooth movement," Journal of Dental Research, vol. 82, no. 3, pp. 177-182, 2003.

[36] C. R. Chung, K. Tsuji, A. Nifuji, T. Komori, K. Soma, and M. Noda, "Micro-CT evaluation of tooth, calvaria and mechanical stress-induced tooth movement in adult Runx2/Cbfa1 heterozygous knock-out mice," Journal of Medical and Dental Sciences, vol. 51, no. 1, pp. 105-113, 2004.
[37] S. Kuroda, T. A. Balam, Y. Sakai, N. Tamamura, and T. TakanoYamamoto, "Expression of osteopontin mRNA in odontoclasts revealed by in situ hybridization during experimental tooth movement in mice," Journal of Bone and Mineral Metabolism, vol. 23, no. 2, pp. 110-113, 2005.

[38] M. Yoshimatsu, Y. Shibata, H. Kitaura et al., "Experimental model of tooth movement by orthodontic force in mice and its application to tumor necrosis factor receptor-deficient mice," Journal of Bone and Mineral Metabolism, vol. 24, no. 1, pp. 20-27, 2006.

[39] H. Kitaura, M. Yoshimatsu, Y. Fujimura et al., "An anti-cFms antibody inhibits orthodontic tooth movement," Journal of Dental Research, vol. 87, no. 4, pp. 396-400, 2008.

[40] E. Storey, “Tissue response to the movement of bones," The American Journal of Orthodontics, vol. 64, no. 3, pp. 229-247, 1973.

[41] K. Yokoya, T. Sasaki, and Y. Shibasaki, "Distributional changes of osteoclasts and pre-osteoclastic cells in periodontal tissues during experimental tooth movement as revealed by quantitative immunohistochemistry of $\mathrm{H}(+)$-ATPase," Journal of Dental Research, vol. 76, no. 1, pp. 580-587, 1997.

[42] V. Krishnan and Z. Davidovitch, "On a path to unfolding the biological mechanisms of orthodontic tooth movement," Journal of Dental Research, vol. 88, no. 7, pp. 597-608, 2009.

[43] J. J. Lowney, L. A. Norton, D. M. Shafer, and E. F. Rossomando, "Orthodontic forces increase tumor necrosis factor $\alpha$ in the human gingival sulcus," The American Journal of Orthodontics and Dentofacial Orthopedics, vol. 108, no. 5, pp. 519-524, 1995.

[44] S. Uematsu, M. Mogi, and T. Deguchi, "Interleukin (IL)-1 $\beta$, IL6 , tumor necrosis factor- $\alpha$, epidermal growth factor, and $\beta 2$ microglobulin levels are elevated in gingival crevicular fluid during human orthodontic tooth movement," Journal of Dental Research, vol. 75, no. 1, pp. 562-567, 1996.

[45] T. Ogasawara, Y. Yoshimine, T. Kiyoshima et al., "In situ expression of RANKL, RANK, osteoprotegerin and cytokines in osteoclasts of rat periodontal tissue," Journal of Periodontal Research, vol. 39, no. 1, pp. 42-49, 2004.

[46] I. Andrade Jr., T. A. Silva, G. A. B. Silva, A. L. Teixeira, and M. M. Teixeira, "The role of tumor necrosis factor receptor type 1 in orthodontic tooth movement," Journal of Dental Research, vol. 86, no. 11, pp. 1089-1094, 2007.

[47] Y. Gao, I. Morita, N. Maruo, T. Kubota, S. Murota, and T. Aso, "Expression of IL-6 receptor and GP130 in mouse bone marrow cells during osteoclast differentiation," Bone, vol. 22, no. 5, pp. 487-493, 1998.

[48] S. Kotake, N. Udagawa, N. Takahashi et al., "IL-17 in synovial fluids from patients with rheumatoid arthritis is a potent stimulator of osteoclastogenesis," The Journal of Clinical Investigation, vol. 103, no. 9, pp. 1345-1352, 1999.

[49] S. W. Fox, K. Fuller, K. E. Bayley, J. M. Lean, and T. J. Chambers, "TGF- $\beta 1$ and IFN- $\gamma$ direct macrophage activation by TNF- $\alpha$ to osteoclastic or cytocidal phenotype," The Journal of Immunology, vol. 165, no. 9, pp. 4957-4963, 2000.

[50] H. Kitaura, N. Nagata, Y. Fujimura et al., "Interleukin-4 directly inhibits tumor necrosis factor- $\alpha$-mediated osteoclast formation in mouse bone marrow macrophages," Immunology Letters, vol. 88, no. 3, pp. 193-198, 2003. 
[51] T. Fujii, H. Kitaura, K. Kimura, Z. W. Hakami, and T. TakanoYamamoto, "IL-4 inhibits TNF-alpha-mediated osteoclast formation by inhibition of RANKL expression in TNF-alphaactivated stromal cells and direct inhibition of TNF-alphaactivated osteoclast precursors via a T-cell-independent mechanism in vivo," Bone, vol. 51, no. 4, pp. 771-780, 2012.

[52] J. M. Owens, A. C. Gallagher, and T. J. Chambers, "IL-10 modulates formation of osteoclasts in murine hemopoietic cultures," The Journal of Immunology, vol. 157, no. 2, pp. 936940, 1996.

[53] N. J. Horwood, J. Elliott, T. J. Martin, and M. T. Gillespie, "IL-12 alone and in synergy with IL-18 inhibits osteoclast formation in vitro," The Journal of Immunology, vol. 166, no. 8, pp. 4915-4921, 2001.

[54] N. Nagata, H. Kitaura, N. Yoshida, and K. Nakayama, "Inhibition of RANKL-induced osteoclast formation in mouse bone marrow cells by IL-12: involvement of IFN $-\gamma$ possibly induced from non-T cell population," Bone, vol. 33, no. 4, pp. 721-732, 2003.

[55] H. Kitaura, N. Nagata, Y. Fujimura, H. Hotokezaka, N. Yoshida, and K. Nakayama, "Effect of IL-12 on TNF- $\alpha$-mediated osteoclast formation in bone marrow cells: apoptosis mediated by Fas/Fas ligand interaction," The Journal of Immunology, vol. 169, no. 9, pp. 4732-4738, 2002.

[56] M. Yoshimatsu, H. Kitaura, Y. Fujimura et al., "IL-12 inhibits TNF- $\alpha$ induced osteoclastogenesis via a T cell-independent mechanism in vivo," Bone, vol. 45, no. 5, pp. 1010-1016, 2009.

[57] Y. Onoe, C. Miyaura, T. Kaminakayashiki et al., "IL-13 and IL-4 inhibit bone resorption by suppressing cyclooxygenase-2dependent prostaglandin synthesis in osteoblasts," The Journal of Immunology, vol. 156, no. 2, pp. 758-764, 1996.

[58] N. Udagawa, N. J. Horwood, J. Elliott et al., "Interleukin-18 (interferon- $\gamma$-inducing factor) is produced by osteoblasts and acts via granulocyte/macrophage colony-stimulating factor and not via interferon- $\gamma$ to inhibit osteoclast formation," The Journal of Experimental Medicine, vol. 185, no. 6, pp. 1005-1012, 1997.

[59] H. Kitaura, M. Tatamiya, N. Nagata et al., "IL-18 induces apoptosis of adherent bone marrow cells in TNF- $\alpha$ mediated osteoclast formation in synergy with IL-12," Immunology Letters, vol. 107, no. 1, pp. 22-31, 2006.

[60] Y. Morita, H. Kitaura, M. Yoshimatsu et al., "IL-18 inhibits TNF$\alpha$-induced osteoclastogenesis possibly via a T cell-independent mechanism in synergy with IL-12 in vivo," Calcified Tissue International, vol. 86, no. 3, pp. 242-248, 2010.

[61] H. Kohara, H. Kitaura, Y. Fujimura et al., "IFN- $\gamma$ directly inhibits TNF- $\alpha$-induced osteoclastogenesis in vitro and in vivo and induces apoptosis mediated by Fas/Fas ligand interactions," Immunology Letters, vol. 137, no. 1-2, pp. 53-61, 2011.

[62] A. A. Celebi, S. Demirer, B. Catalbas, and S. Arikan, "Effect of ovarian activity on orthodontic tooth movement and gingival crevicular fluid levels of interleukin- $1 \beta$ and prostaglandin $\mathrm{E}_{2}$ in cats," The Angle Orthodntist, vol. 83, no. 1, pp. 70-75, 2013.

[63] D. F. Madureira, A. Taddei Sde, M. H. Abreu et al., "Kinetics of interleukin- 6 and chemokine ligands 2 and 3 expression of periodontal tissues during orthodontic tooth movement," The American Journal of Orthodontics and Dentofacial Orthopedics, vol. 142, no. 4, pp. 494-500, 2012.

[64] N. Hamamc1, F. Acun Kaya, E. Uysal, and B. Yokuş, "Identification of interleukin 2, 6, and 8 levels around miniscrews during orthodontic tooth movement," European Journal of Orthodontics, vol. 34, no. 3, pp. 357-361, 2012.
[65] G. Başaran, T. Özer, F. A. Kaya, and O. Hamamci, "Interleukins 2,6 , and 8 levels in human gingival sulcus during orthodontic treatment," The American Journal of Orthodontics and Dentofacial Orthopedics, vol. 130, no. 1, pp. 7.e1-7.e6, 2006.

[66] M. Yamaguchi, "RANK/RANKL/OPG during orthodontic tooth movement," Orthodontics and Craniofacial Research, vol. 12, no. 2, pp. 113-119, 2009.

[67] M. Kaku, M. Motokawa, Y. Tohma et al., "VEGF and M-CSF levels in periodontal tissue during tooth movement," Biomedical Research, vol. 29, no. 4, pp. 181-187, 2008.

[68] T. P. Garlet, U. Coelho, J. S. Silva, and G. P. Garlet, "Cytokine expression pattern in compression and tension sides of the periodontal ligament during orthodontic tooth movement in humans," European Journal of Oral Sciences, vol. 115, no. 5, pp. 355-362, 2007.

[69] H. Kohara, H. Kitaura, M. Yoshimatsu et al., "Inhibitory effect of interferon- $\gamma$ on experimental tooth movement in mice," Journal of Interferon \& Cytokine Research, vol. 32, no. 9, pp. 426-431, 2007.

[70] N. Alhashimi, L. Frithiof, P. Brudvik, and M. Bakhiet, "Orthodontic movement induces high numbers of cells expressing IFN- $\gamma$ at mRNA and protein levels," Journal of Interferon and Cytokine Research, vol. 20, no. 1, pp. 7-12, 2000.

[71] M. Yoshimatsu, H. Kitaura, Y. Fujimura et al., "Inhibitory effects of IL-12 on experimental tooth movement and root resorption in mice," Archives of Oral Biology, vol. 57, no. 1, pp. 36-43, 2012.

[72] P. J. Brooks, A. F. Heckler, K. Wei, and S.-G. Gong, "MCSF accelerates orthodontic tooth movement by targeting preosteoclasts in mice," Angle Orthodontist, vol. 81, no. 2, pp. 277-283, 2011.

[73] L. J. Murray, T. J. Abrams, K. R. Long et al., "SU11248 inhibits tumor growth and CSF-1R-dependent osteolysis in an experimental breast cancer bone metastasis model," Clinical and Experimental Metastasis, vol. 20, no. 8, pp. 757-766, 2003.

[74] A. L. Dewar, A. C. W. Zannettino, T. P. Hughes, and A. B. Lyons, "Inhibition of c-fms by imatinib: expanding the spectrum of treatment," Cell Cycle, vol. 4, no. 7, pp. 851-853, 2005.

[75] M. C. Genovese, S. Cohen, L. Moreland et al., "Combination therapy with etanercept and anakinra in the treatment of patients with rheumatoid arthritis who have been treated unsuccessfully with methotrexate," Arthritis and Rheumatism, vol. 50, no. 5, pp. 1412-1419, 2004.

[76] E. Chan and M. A. Darendeliler, "Physical properties of root cementum. Part 5: volumetric analysis of root resorption craters after application of light and heavy orthodontic forces," The American Journal of Orthodontics and Dentofacial Orthopedics, vol. 127, no. 2, pp. 186-195, 2005.

[77] D. A. Harris, A. S. Jones, and M. A. Darendeliler, "Physical properties of root cementum. Part 8: volumetric analysis of root resorption craters after application of controlled intrusive light and heavy orthodontic forces: a microcomputed tomography scan study," The American Journal of Orthodontics and Dentofacial Orthopedics, vol. 132, no. 3, p. 277, 2006.

[78] G. T. Sameshima and K. O. Asgarifar, "Assessment of root resorption and root shape: periapical vs panoramic films," Angle Orthodontist, vol. 71, no. 3, pp. 185-189, 2001.

[79] G. T. Sameshima and P. M. Sinclair, "Predicting and preventing root resorption. Part II: treatment factors," The American Journal of Orthodontics and Dentofacial Orthopedics, vol. 119, no. 5, pp. 511-515, 2001.

[80] G. Han, S. Huang, J. W. von den Hoff, X. Zeng, and A. M. Kuijpers-Jagtman, "Root resorption after orthodontic intrusion 
and extrusion: an intraindividual study," Angle Orthodontist, vol. 75, no. 6, pp. 912-918, 2005.

[81] S. Sringkarnboriboon, Y. Matsumoto, and K. Soma, "Root resorption related to hypofunctional periodontium in experimental tooth movement," Journal of Dental Research, vol. 82, no. 6, pp. 486-490, 2003.

[82] R. A. Al-Qawasmi, J. K. Hartsfield Jr., E. T. Everett et al., "Genetic predisposition to external apical root resorption in orthodontic patients: linkage of chromosome-18 marker," Journal of Dental Research, vol. 82, no. 5, pp. 356-360, 2003.

[83] N. Alhashimi, L. Frithiof, P. Brudvik, and M. Bakhiet, "CD40CD40L expression during orthodontic tooth movement in rats," Angle Orthodontist, vol. 74, no. 1, pp. 100-105, 2004.

[84] M. Nishioka, H. Ioi, S. Nakata, A. Nakasima, and A. Counts, "Root resorption and immune system factors in the Japanese," Angle Orthodontist, vol. 76, no. 1, pp. 103-108, 2006.

[85] K. Takada, H. Kajiya, H. Fukushima, F. Okamoto, W. Motokawa, and K. Okabe, "Calcitonin in human odontoclasts regulates root resorption activity via protein kinase A," Journal of Bone and Mineral Metabolism, vol. 22, no. 1, pp. 12-18, 2004.

[86] C. Verna, L. E. Hartig, S. Kalia, and B. Melsen, "Influence of steroid drugs on orthodontically induced root resorption," Orthodontics \& Craniofacial Research, vol. 9, no. 1, pp. 57-62, 2006.

[87] H. Kitaura, Y. Fujimura, M. Yoshimatsu et al., "An M-CSF receptor c-Fms antibody inhibits mechanical stress-induced root resorption during orthodontic tooth movement in mice," Angle Orthodontist, vol. 79, no. 5, pp. 835-841, 2009.

[88] T. Sasaki, "Differentiation and functions of osteoclasts and odontoclasts in mineralized tissue resorption," Microscopy Research and Technique, vol. 61, no. 6, pp. 483-495, 2003.

[89] M. Tsuchiya, Y. Akiba, I. Takahashi et al., "Comparison of expression patterns of cathepsin K and MMP-9 in odontoclasts and osteoclasts in physiological root resorption in the rat molar," Archives of Histology and Cytology, vol. 71, no. 2, pp. 89100, 2008. 


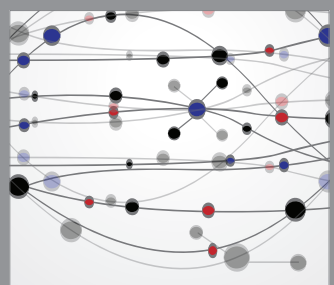

The Scientific World Journal
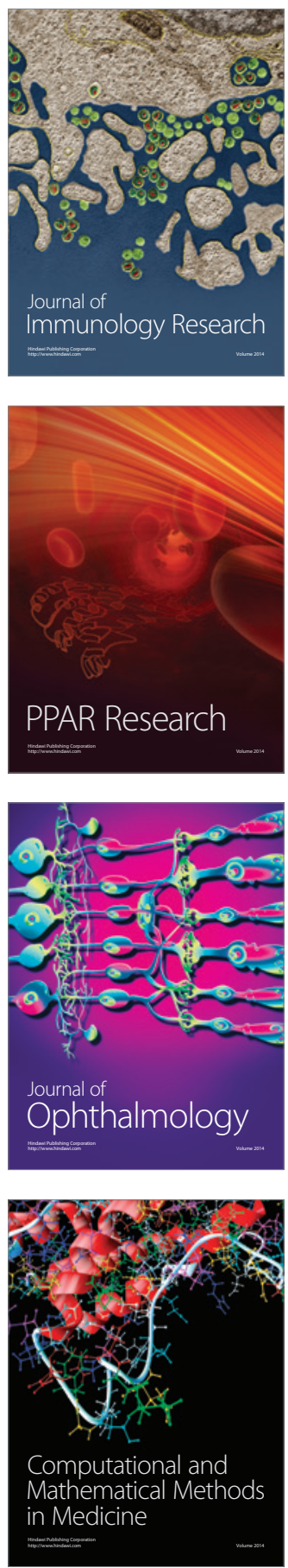

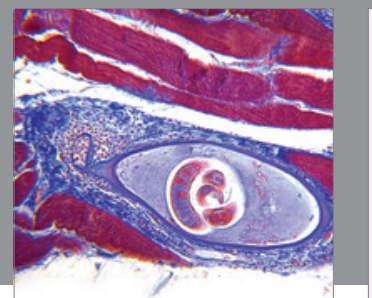

Gastroenterology

Research and Practice
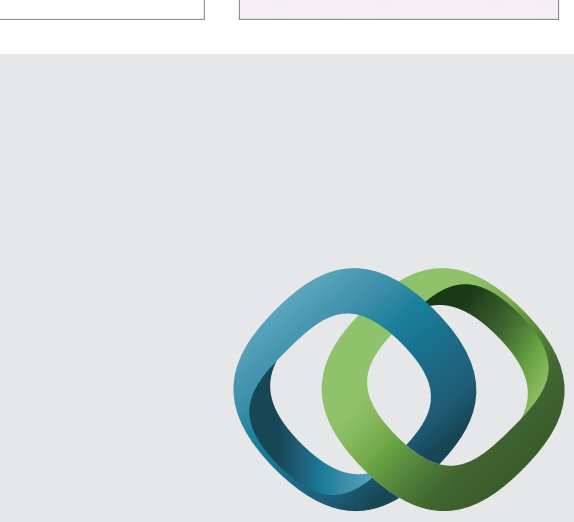

\section{Hindawi}

Submit your manuscripts at

http://www.hindawi.com
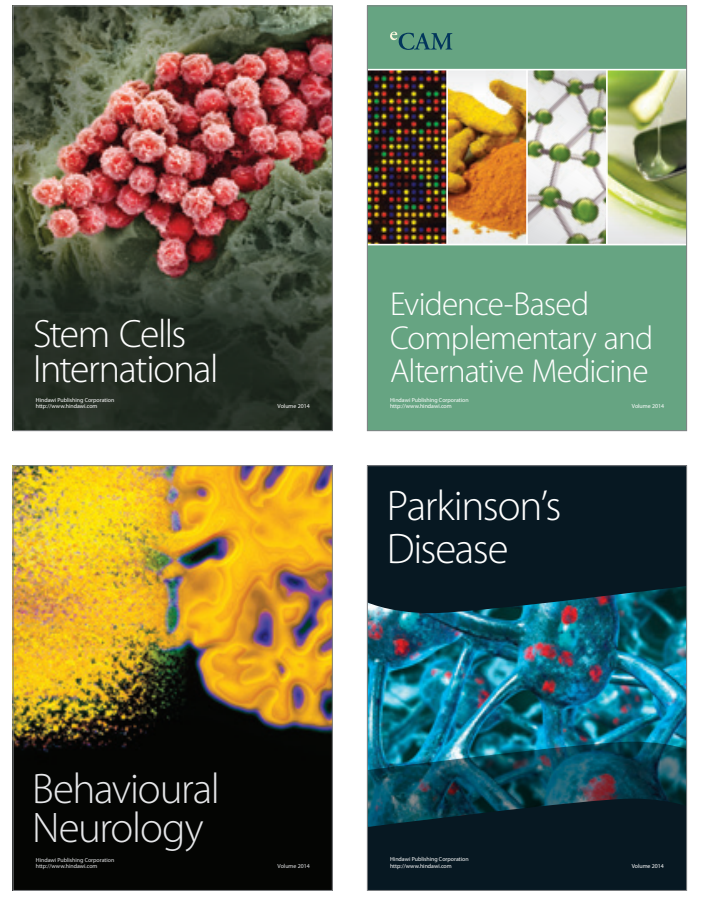
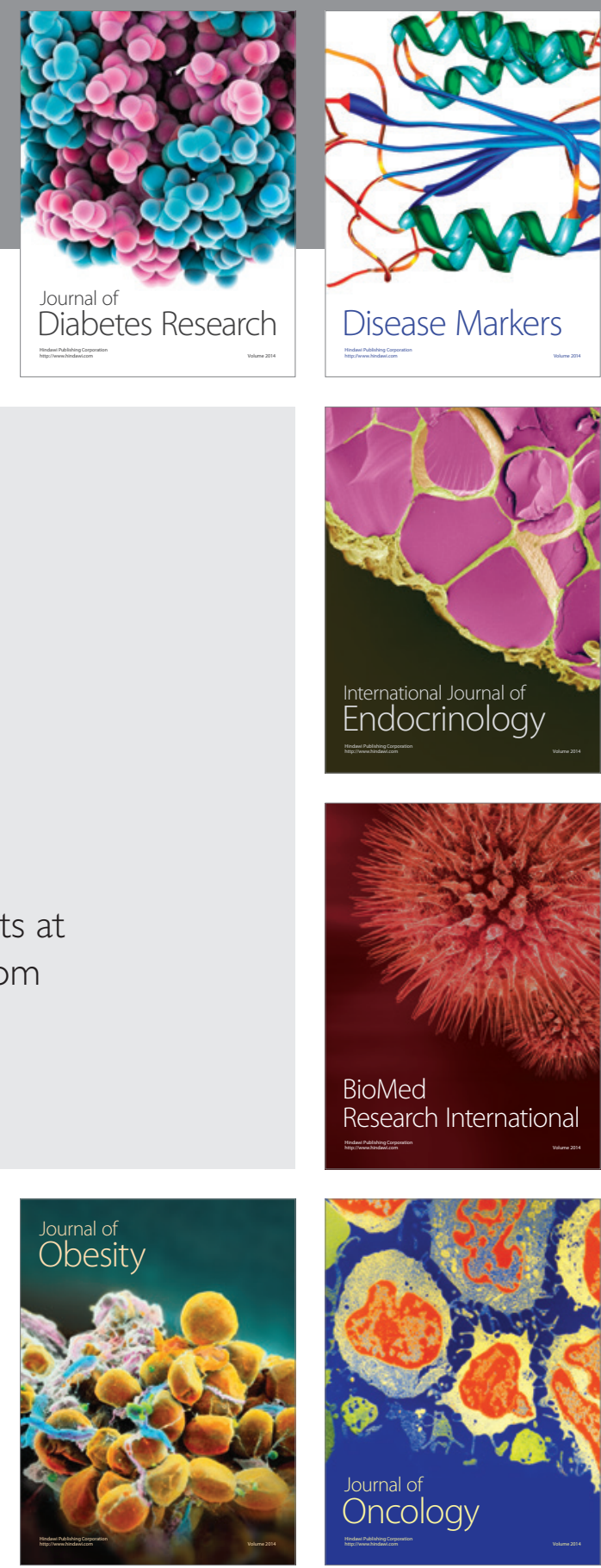

Disease Markers
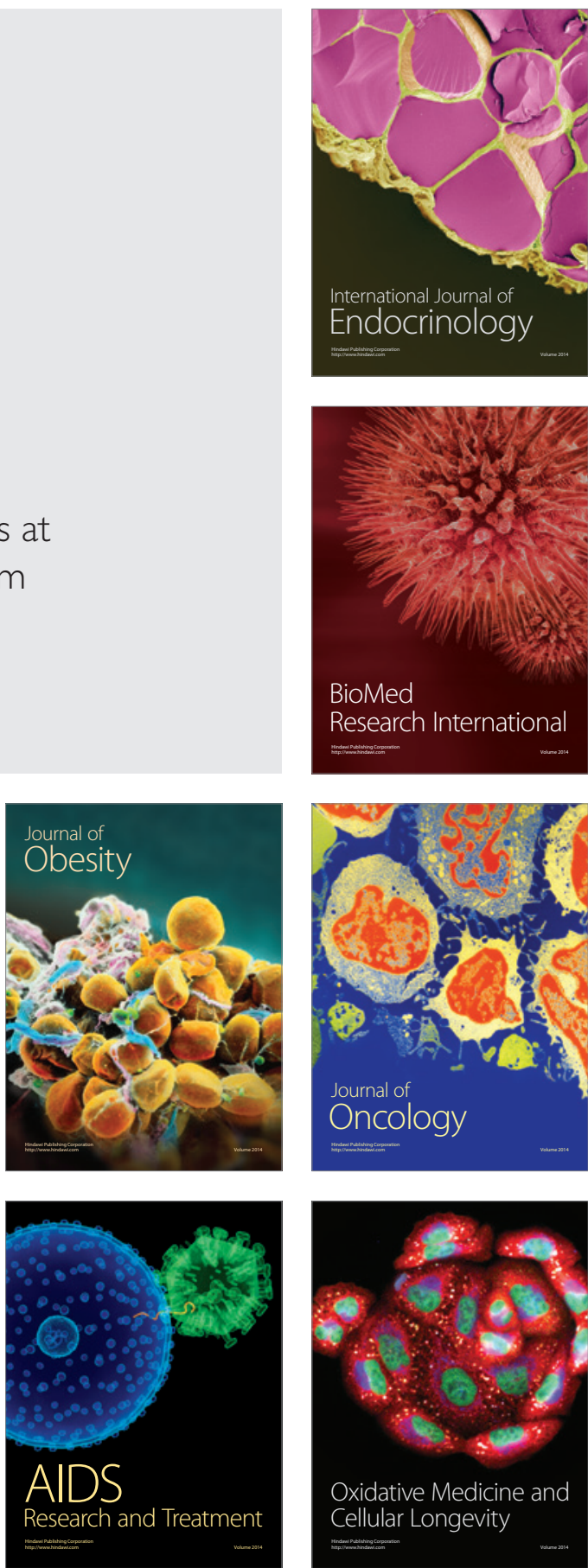